\title{
Mortality among flavour and fragrance chemical plant workers in the United States
}

\author{
T L THOMAS
}

From the Occupational Studies Section, Environmental Epidemiology Branch, National Cancer Institute, Bethesda, MD 20892, USA

ABSTRACT Vital status on 1 January 1981 was determined for a cohort of 1412 white men employed in a flavour and fragrance chemical plant between 1945 and 1965 in order to investigate the risks from fatal diseases among men exposed to multiple chemicals in the manufacture of fragrances, flavours, aroma chemicals, and other organic substances. Cause specific standardised mortality ratios (SMRs) were calculated for the entire study population and for several subsets by likelihood of exposure to chemicals, duration of employment, and year of hire. SMRs for rectal cancer and ischaemic heart disease were raised among white male employees whose jobs were in production, maintenance, laboratory, or other jobs that would involve exposure to multiple chemicals used and produced in the plant. The excess of rectal cancer was confined to employees who had worked as chemical operators and mortality was significantly raised among men who worked for ten or more years. Traces of dioxin were recently found in and around plant buildings that used trichlorophenol in the production of hexachlorophene. The study group was small and had limited power to detect excess risk of rare causes of death; however, no soft tissue sarcomas were observed during the study period.

The present study began as an investigation of the risk of fatal disease among a cohort of workers in a multiple chemical exposure workplace. Flavour and fragrance manufacturing is a specialised subset of the chemical industry that produces fragrances, flavours, aroma chemicals, and other organic chemicals as additives for soaps, cosmetics, and other products. The plant studied (plant X) is in a United States East Coast urban area and has been in operation since about 1928 . Numerous potentially hazardous substances are currently used or have been used in the past at this plant in the production of crude essential oils and chemical additives. These include nickel, trichlorophenol, benzene, ethylene dichloride, xylene, toluene, carbon tetrachloride, cinnamyl anthranilate, and hundreds of others.

The Oil, Chemical, and Atomic Workers International Union, which represents workers at plant $\mathrm{X}$, requested that the National Cancer Institute conduct a retrospective cohort mortality study of workers at plant $\mathbf{X}$ to determine whether the numerous chemical exposures might contribute to an increased risk of fatal disease. The company provided access to personnel files and data collection began in $\mathbf{1 9 8 2}$.

Accepted 2 December 1986
In addition to hundreds of other chemical additives, hexachlorophene has been manufactured at plant X since the early 1940 s, using a highly purified form of 2,4,5-trichlorophenol (TCP) as a raw material. Because even highly purified TCP sometimes contains 2,3,7,8-tetrachlorodibenzodioxin (TCDD) as a contaminant, the company conducted an investigation in 1983 to determine whether TCDD was present in or around plant $X$. Traces of TCDD were found in about half the soil and other samples obtained; most of the positive samples showed levels of less than $1 \mathrm{ppb}$ TCDD. Wipe and dust samples from inside several of the buildings showed traces of TCDD greater than $1 \mathrm{ppb}$ in only one of the three buildings currently engaged in hexachlorophene production, in one building that was a former site of TCP production, and in two buildings not known to be engaged in hexachlorophene production.

\section{Materials and methods}

A study group of all hourly and salaried employees who worked at plant $X$ for at least one day between 1 January 1945 and 31 December 1965 was identified from company rosters and personnel files. Information abstracted from records of each study subject included identifying information, sex, race, dates 
employed at the plant, and work history. The latter was limited to each job title held by the employee and the dates worked in the job. No information was available to identify the buildings in which an employee had worked. Hexachlorophene production was confined to certain buildings; thus without building location there was no way to identify which workers were potentially exposed to TCDD. Each job held by a study subject at the plant was classified into the following categories: (1) chemical operator (production, support); (2) maintenance worker (mechanical, machinist, carpenter); (3) compounder, weigher, bulker, labeller; (4) shipping and receiving (material handler); (5) laboratory worker (dishwasher, container cleaner); (6) plant chemist; (7) engineer/ draftsman; (8) research and development specialist (office); (9) clerk/administrator (office); (10) warehouse worker; and (11) safety (fireman, watchman). The nature of operations at the plant resulted in potential exposure to numerous chemicals, particularly for production, laboratory, and maintenance workers. Products manufactured in specific areas or buildings changed often and required the use of multiple chemicals.

The subjects were followed up to determine their vital status on 1 January 1981 using records from the company, Social Security Administration, credit bureaus, and departments of motor vehicles. Subjects reported to have died after 1 January 1981 were counted as alive at the end of the study. Death certificates for study subjects identified as dead were obtained from appropriate state vital records offices and were coded by a qualified nosologist according to the rules in effect at the time of death but using eighth revision ICDA numbers. ${ }^{1}$

Person-years at risk of fatal disease were accumulated for each study subject beginning with the later of 1 January 1945 or date of hire and ending on the date the study subject was last known to be alive. The observed numbers of deaths in the study group were totalled for specific causes. Corresponding expected numbers were calculated by multiplying cause specific death rates for United States white men by personyears at risk in the study group with appropriate adjustments for sex, race, age, and calendar time. ${ }^{2}$ Expected numbers of deaths from cancer were also obtained using death rates from the state in which the plant is located. Local rates for other causes were not available in the appropriate computerised format. Standardised mortality ratios (SMRs) were calculated as the ratio of observed to expected deaths. Statistical significance of the SMRs was determined by using a Mantel-Haenszel chi square test with one degree of freedom. ${ }^{3}$ SMRs and significance tests were not calculated when the observed and expected numbers of deaths for a specific cause were both less than two.
Results based on less than five observed deaths $\frac{\text { Thomas }}{\overline{\frac{\pi}{c}}}$
appear in parentheses.

In several of the analyses study subjects were cate? gorised according to their likelihood of exposure tof chemicals used and produced at plant X. Subjects who had worked only in administrative, clerical drafting/engineering, and research/development jobs were classified into the "minimal chemical exposure" group. Warehousers, shipping and receiving materiaP handlers, firemen, and watchmen were assumed tô have "moderate chemical exposure." Those who eve 5 worked as chemical operators, maintenance workers; compounders, laboratory workers, or plant chemistsw were categorised in the "maximum chemicas exposure" category. Eighty seven per cent of the employees had held jobs in the last category.

In calculating expected numbers of deaths by duration of employment, all subjects contributed $\sqsubset$ person-years at risk in the less than one year category Workers employed at least one but less than 10 years were considered at risk in the one to 9.9 year categorys at the end of their first year of employment. For workers employed more than ten years, person-years at risk were allocated to each duration category as appropriate; thus they were not considered at risk in 3 the $>10$ category until they reached their tenth yearo of employment.

In analyses by employment status activ\&1500 employed study subjects were considered at risk of dying until three months after the date they lâs: worked. Person-years at risk for terminated workêrs began three months after they last worked.

\section{Results}

Over $80 \%$ of the subjects were white men. There were insufficient numbers of women $(n=228)$ and nonwhite men $(n=81)$ to conduct separate analyses? thus they were excluded from further consideration Five study subjects whose race was unknown and four white men whose dates of employment were unknown were also excluded from the analyses.

A total of 952 white male employees was known too be alive at the end of the study. Among these were 473 study subjects who died subsequently. Of the 395 meno who died during the study period, death certificates? were not found for 32 . These 32 were counted as losto as were the $5 \%$ of the study group $(n=65)$ whose vital status at the end of the study was unknown. O

Of the 1412 white men in the study group whoser employment dates were known, most (958) were hired between 1945 and $1954 ; 82 \%$ were hired before the age of 40 . Altogether 631 employees $(45 \%)$ worked at the plant for less than one year whereas 434 (about $31 \%$ ) worked at the plant for ten or more years.

A total of 36368 person-years at risk was accumu- 
lated by white men in the study group. Table 1 shows the SMRs for the major causes of death among these subjects. The all causes SMR was slightly less than 1.0. There was a significant excess of deaths due to ischaemic heart disease. The number of deaths from malignant neoplasms was not greater than expected but there was a statistically significant excess of benign and unspecified neoplasms. The number of deaths from violent causes was significantly lower than expected.

The SMR for all digestive cancer was raised (table 2) due to excess mortality from cancers of the stomach, rectum, and pancreas. The observed number of deaths from lung cancer was slightly greater than expected but the SMR was not statistically significant. SMRs for lymphatic and haematopoietic malignancies and for all other cancer sites combined were less than one. Similar patterns were seen when state rates were used to calculate the expected numbers of death; however, the SMR for all digestive cancer was close to $1 \cdot 0$. There were no observed deaths from soft tissue sarcoma in the study group.

Table 3 shows the mortality patterns for digestive and rectal cancer by likelihood of exposure to chemicals, year of hire, duration of employment, and year of birth. Digestive cancer mortality was excessive among men whose likelihood of chemical exposure was minimum or moderate. The four workers with rectal cancer in the "maximum exposure" category had all worked as chemical operators (expected number of deaths $=1 \cdot 10$, SMR $=3 \cdot 65$ ). A fifth chemical operator died from rectal cancer after the study end date. All the cases of digestive cancer occurred among men hired before 1955. Among men hired before 1945 there was a significant excess of deaths from rectal cancer. No association between duration of employment and risk of digestive cancer was detected; however, mortality from rectal cancer was significantly raised among men who worked for ten or more years. Analyses by year of birth indicated an excess of digestive cancer among study subjects born before 1920 and a slight deficit among those born in 1920 or later.

There was a significant excess of mortality from ischaemic heart disease among workers whose likelihood of chemical exposure was the maximum and there were fewer deaths than expected in the "minimum" exposure category (table 4). SMRs for ischaemic heart disease were raised only among men hired after 1945. A significant excess mortality

Table 1 SMRs for major causes of death among white male flavour and fragrance chemical plant workers, $1945-82$

\begin{tabular}{|c|c|c|c|}
\hline Underlying cause of death (8th rev, ICDA) & Observed deaths & Expected deaths & $S M R$ \\
\hline $\begin{array}{l}\text { All causes of death } \\
\text { Infectious and parasitic disease }(000-139) \\
\text { Malignant neoplasms }(140-209) \\
\text { Benign and unspecified neoplasms }(210-239) \\
\text { Diseases of circulatory system }(390-458) \\
\text { Ischaemic heart disease }(410-413) \\
\text { Vascular lesions of central nervous system (430-438) } \\
\text { Respiratory diseases }(460-519) \\
\text { Diseases of digestive system }(520-577) \\
\text { Accident, suicide, homicide }(800-998) \\
\text { All other causes }\end{array}$ & $\begin{array}{c}363 \\
5 \\
77 \\
5 \dagger \\
207 \\
170 \\
20 \\
16 \\
22 \\
15 \\
16\end{array}$ & $\begin{array}{r}389.1 \\
5.8 \\
77.7 \\
1.1 \\
197.9 \\
138.7 \\
24.6 \\
22.0 \\
20.0 \\
40.0 \\
24.6\end{array}$ & $\begin{array}{l}0.93 \\
0.86 \\
0.99 \\
4.50^{*} \\
1.05 \\
1.23^{*} \\
0.81 \\
0.73 \\
1 \cdot 10 \\
0.37^{*} \\
0.65\end{array}$ \\
\hline
\end{tabular}

$* p<0.01$.

tIncludes three benign neoplasms without specification of site, one unspecified lung neoplasm, and one unspecified central nervous system neoplasm.

Note: Expected deaths were calculated using United States white men as the referent population.

Table 2 SMRs for selected cancers among white male flavour and fragrance chemical plant workers, $1945-82$

\begin{tabular}{|c|c|c|c|c|c|}
\hline \multirow[b]{2}{*}{ Underlying cause of death (8th rev, ICDA) } & \multicolumn{3}{|c|}{ United States rates } & \multicolumn{2}{|l|}{ State rates } \\
\hline & Observed deaths & Expected deaths & $U S S M R$ & Expected deaths & State $S M R$ \\
\hline $\begin{array}{l}\text { Digestive cancer (150-159) } \\
\text { Oesophagus (150) } \\
\text { Stomach (151) } \\
\text { Large intestine (153) } \\
\text { Rectum (154) } \\
\text { Liver (155) } \\
\text { Pancreas (157) } \\
\text { Cancer of lung (162) }\end{array}$ & $\begin{array}{r}28 \\
3 \\
6 \\
4 \\
6 \\
0 \\
6 \\
29\end{array}$ & $\begin{array}{r}21 \cdot 7 \\
1 \cdot 9 \\
4 \cdot 2 \\
6 \cdot 9 \\
2 \cdot 5 \\
1 \cdot 6 \\
4 \cdot 2 \\
25 \cdot 1\end{array}$ & $\begin{array}{c}1.29 \\
(1.62) \\
1.44 \\
(0.58) \\
2.45 \\
1.42 \\
1.15\end{array}$ & $\begin{array}{r}27 \cdot 1 \\
2 \cdot 2 \\
5 \cdot 2 \\
8 \cdot 9 \\
3 \cdot 5 \\
1 \cdot 4 \\
4 \cdot 6 \\
26 \cdot 7\end{array}$ & $\begin{array}{c}1 \cdot 03 \\
(1 \cdot 38) \\
1 \cdot 15 \\
(0.45) \\
1 \cdot 70 \\
-\quad \\
1.31 \\
1.09\end{array}$ \\
\hline $\begin{array}{l}\text { Lymphatic and haematopoietic cancer } \\
(200-209) \\
\text { All other cancer sites }\end{array}$ & $\begin{array}{r}6 \\
14\end{array}$ & $\begin{array}{r}7 \cdot 7 \\
23 \cdot 1\end{array}$ & $\begin{array}{l}0.78 \\
0.61\end{array}$ & $\begin{array}{r}6 \cdot 0 \\
21 \cdot 7\end{array}$ & $\begin{array}{l}1.00 \\
0.64\end{array}$ \\
\hline
\end{tabular}


Table 3 Mortality from digestive cancer among white male flavour and fragrance chemical plant workers, 1945-82

\begin{tabular}{|c|c|c|c|c|c|c|}
\hline & \multicolumn{3}{|c|}{ All digestive cancer } & \multicolumn{3}{|l|}{ Rectal cancer } \\
\hline & Observed deaths & Expected deaths & $S M R$ & Observed deaths & Expected deaths & $S M R$ \\
\hline $\begin{array}{c}\text { Likelihood of } \\
\text { Minimum } \\
\text { Moderate } \\
\text { Maximum }\end{array}$ & $\begin{array}{r}2 \\
5 \\
21\end{array}$ & $\begin{array}{r}0.7 \\
1 \cdot 7 \\
19 \cdot 0\end{array}$ & $\begin{array}{l}(2.97) \\
2.89 \\
1 \cdot 11\end{array}$ & $\begin{array}{l}1 \\
1 \\
4\end{array}$ & $\begin{array}{l}0 \cdot 1 \\
0 \cdot 2 \\
2 \cdot 1\end{array}$ & $\begin{array}{l}\overline{-} \\
(1 \cdot 87)\end{array}$ \\
\hline $\begin{array}{c}\text { Year of hire: } \\
<1945 \\
1945-1954 \\
1955-1964\end{array}$ & $\begin{array}{r}9 \\
19 \\
0\end{array}$ & $\begin{array}{r}7 \cdot 3 \\
13 \cdot 2 \\
1 \cdot 2\end{array}$ & $\begin{array}{l}1.23 \\
1.44 \\
-\end{array}$ & $\begin{array}{l}4 \\
2 \\
0\end{array}$ & $\begin{array}{l}0.9 \\
1.5 \\
0.1\end{array}$ & $\begin{array}{l}(4 \cdot 60)^{*} \\
(1 \cdot 37)\end{array}$ \\
\hline $\begin{array}{l}\text { Duration of er } \\
<1 \\
1-9 \cdot 9 \\
\geqslant 10\end{array}$ & $\begin{array}{r}9 \\
6 \\
13\end{array}$ & $\begin{array}{l}7 \cdot 5 \\
5 \cdot 7 \\
8 \cdot 5\end{array}$ & $\begin{array}{l}1.20 \\
1.05 \\
1.53\end{array}$ & $\begin{array}{l}2 \\
0 \\
4\end{array}$ & $\begin{array}{l}0.8 \\
0.7 \\
1.0\end{array}$ & $\frac{(2 \cdot 42)}{(4 \cdot 14)^{*}}$ \\
\hline $\begin{array}{c}\text { Year of birth: } \\
1881-1919 \\
1920-1946\end{array}$ & $\begin{array}{r}27 \\
1\end{array}$ & $\begin{array}{r}18.5 \\
3.1\end{array}$ & $\begin{array}{c}1.46 \\
(0.32)\end{array}$ & $\begin{array}{l}5 \\
1\end{array}$ & $\begin{array}{l}2 \cdot 1 \\
0.3\end{array}$ & $2 \cdot 34$ \\
\hline
\end{tabular}

Note: Expected deaths were calculated using United States white men as the referent population.

Table 4 Mortality from arteriosclerotic heart disease among white male flavour and fragrance chemical plant workers, 1945-82

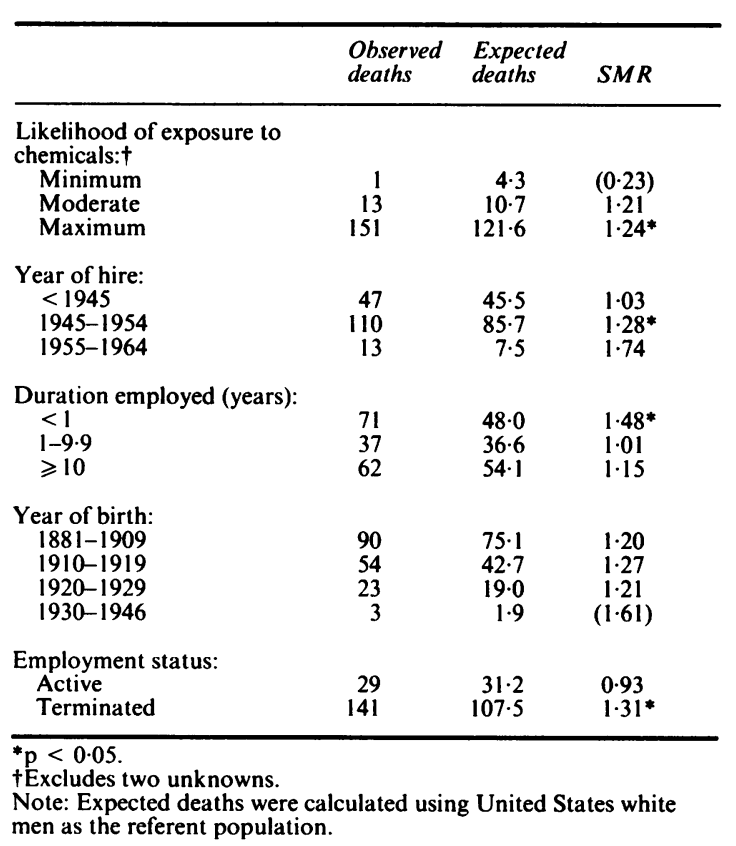

occurred among men employed for less than one year but not among those who worked longer. No relation was seen by year of birth. Analyses by employment status indicated that mortality from ischaemic heart disease was close to that expected among actively employed workers and significantly raised among $\overrightarrow{8}$ those who had terminated their employment.

\section{Discussion}

Caution should be used in interpreting results of thiso study because the total number of study subjects woth long term employment at the plant is small, and this the statistical power to detect raised risks of rare ${ }_{1} s$ ? eases is minimal. Secondly, this plant represents multiple chemical exposure workplace and for and individual jobs or work areas the list of exposures would be extensive. Finally, there may have been differences in lifestyle characteristics between the study group and the general population (smoking, alcohol consumption, or diet, for example) that could have affected mortality patterns. Despite these lim-itations, the analyses yielded interesting results tha warrant further consideration.

Only one other published report describes the moro tality experience of flavour and fragrance chemicat. plant workers. ${ }^{4}$ A Swiss study which covered aboue the same period as the present study found a sligh? excess of accidental deaths and poisonings whereas the study of plant $X$ employees showed a significant deficit of deaths from these causes. The Swiss stude. did not show a raised SMR for circulatory disease among all employees but found a significant excess risk among workers in chemical compounding pro요 cesses. The SMR for ischaemic heart disease waß raised among compounders at plant $\mathrm{X}(\mathrm{SMR}=1.33 \Phi$ but was not statistically significant. Although the excess mortality from ischaemic heart disease in the study of plant $\mathbf{X}$ employees was not confined to ans? particular production group, employees whose jobso 
had potential for moderate or maximum exposure to chemicals had raised SMR for ischaemic heart disease whereas employees in the minimal exposure group did not. The Swiss study found excess mortality from digestive cancer only among workers first employed between 1900 and 1929 and born before 1900. These findings are somewhat consistent with the plant $\mathrm{X}$ data in which there was a significant excess of rectal cancer among men hired before 1945 and raised SMRs for rectal and all digestive cancer among those born before 1920 .

A raised risk of rectal cancer has been suggested to occur among woodworkers in the automobile industry, ${ }^{5}$ workers in the paint and coatings manufacturing industry, ${ }^{6}$ workers in a plastics producing plant, ${ }^{7}$ workers exposed to polychlorinated biphenyls, ${ }^{8}$ and shoeworkers. ${ }^{9}$ Most of these findings, however, are based on small numbers and no causative agents have been identified. Workers in plant $\mathbf{X}$ might have had some similar occupational exposures as these other occupational groups with raised rectal cancer mortality-for example, industrial solvents.

The raised SMR for ischaemic heart disease among these workers is interesting, particularly because heart disease mortality is usually low in occupational cohorts due to the "healthy worker effect."10 This selection process operates more strongly among younger, actively employed workers, and decreases among old, retired workers. The SMR of 0.93 seen among actively employed workers in plant $\mathrm{X}$ might be higher than expected in an actively employed group, because heart disease is likely to be a factor that would prevent someone from entering the workforce or cause him to leave the workforce early. ${ }^{10}$ Among job related exposures, carbon disulphide, aliphatic nitrates, some industrial solvents, and arsenic have previously been associated with ischaemic heart disease. ${ }^{112}$ Earlier studies showed a raised risk of ischaemic heart disease after short term high level exposures to certain substances ${ }^{11}$; however, the present data are not consistent with these findings because most of the deaths from ischaemic heart disease occurred among terminated workers who were separated from their jobs for more than three months.

Associations between soft tissue sarcomas and occupational exposure to chlorinated phenoxyacetic acids or TCDD contaminated products have been found in United States and Swedish workers. ${ }^{13-15}$ Further examination of the United States cases, however, has reduced the level of suspicion generated by the American studies. ${ }^{16}$ Traces of TCDD were measured in some soil samples from outside and wipe samples from within plant $X$ buildings. In the cohort mortality analysis of plant $\mathrm{X}$ employees there were no observed deaths from soft tissue sarcoma; however, the number expected was only about $0 \cdot 3$. TCDD lev- els measured in 1983 may not be representative of earlier exposures; thus no definitive conclusions regarding exposure to dioxin and soft tissue sarcoma can be drawn from these results.

These results suggest that workers in plant $\mathrm{X}$ may have a raised risk of ischaemic heart disease and rectal cancer but extreme caution must be used in interpreting these results due to study limitations. The excess mortality for ischaemic heart disease among short term workers and terminated workers suggests that some factor other than occupation might be responsible for the overall excess. An evaluation of the risk of soft tissue sarcoma cannot be made based on the small numbers available. Further research with larger numbers of exposed workers is necessary to clarify the findings of this study.

\section{References}

1 World Health Organisation. Manual of the international statistical classification of diseases, injuries, and causes of death. 8th rev (adapted). Geneva: WHO, 1970.

2 Monson RR. Analysis of relative survival and proportional mortality. Comput Biomed Res 1974;7:325-32.

3 Mantel N, Haenszel W. Statistical aspects of the analysis of data from retrospective studies of disease. J Natl Cancer Inst 1959;2:719-48.

4 Guberan E, Raymond L. Mortality and cancer incidence in the perfumery and flavour industry of Geneva. $\mathrm{Br} J$ Ind Med 1985;42:240-5.

5 Swanson GM, Belle SH. Cancer morbidity among woodworkers in the US automotive industry. J Occup Med 1982;24:315-9.

6 Morgan RW, Kaplan SD, Gaffey WR. A general mortality study of production workers in the paint and coatings manufacturing industry. J Occup Med 1981;23:13-21.

7 Marsh GM. Mortality among workers from a plastics producing plant: a matched case-control study nested in a retrospective cohort study. J Occup Med 1983;25:218-30.

8 Brown DP, Jones M. Mortality and industrial hygiene study of workers exposed to polychlorinated biphenyls. Arch Environ Health 1981;36:120-9.

9 Decoufle P, Walrath J. Proportionate mortality among US shoeworkers, 1966-77. Am J Ind Med 1983;4:523-32.

10 McMichael AJ. Standardised mortality ratios and the "healthy worker effect": scratching beneath the surface. $J$ Occup Med 1976;18:165-8.

11 Fine LJ. Occupational heart disease. In: Rom WN, ed. Environmental and occupational medicine. Boston: Little, Brown, and Co, 1983:359-65.

12 Wilcosky TC, Tyroler HA. Mortality from heart disease among workers exposed to solvents. J Occup Med 1983;25:879-85.

13 Hardell L, Sandstrom A. Case-control study: soft-tissue sarcomas and exposure to phenoxyacetic acids or chlorophenols. $\mathrm{Br} J$ Cancer 1979;39:711-7.

14 Eriksson M, Berg N, Hardell L, Moller T, Axelson O. Soft-tissue sarcomas and exposure to chemical substances: a case-referent study. $\mathrm{Br} J$ Ind $\mathrm{Med} 1981 ; 38: 27-33$.

15 Honchar PA, Halperin WE. 2,4,5-Trichlorophenol and soft tissue sarcoma. Lancet 1981;i:268-9.

16 Fingerhut MA, Halperin, WE, Honchar PA, Smith AB, Groth DH, Russell WO. An evaluation of reports of dioxin exposure and soft tissue sarcoma pathology among chemical workers in the United States. Scand J Work Environ Health 1984;10:299-303. 